\title{
CEREBRAL PALSY IN CHILDREN OF VERY LOW BIRTH WEIGHT
}

\author{
BY \\ ALISON D. MCDONALD \\ From the Paediatric Research Unit, Guy's Hospital Medical School, London
}

(RECEIVED FOR PUBLICATION JULY 8, 1963)

It has been known since Little's time that a high proportion of children with cerebral palsy are premature and that many are very small at birth. A study of the relation between the group of disorders included under the term cerebral palsy and very low birth weight was undertaken in the hope that it might contribute useful aetiological information. This report describes the results of a survey, made in collaboration with the Society of Medical Officers of Health, of 1,081 surviving children weighing not more than $4 \mathrm{lb}$. $(1,800 \mathrm{~g}$.) at birth. Taking into account the frequency of so low a birth weight, and the high mortality that it carries (Gibson and McKeown, 1951), it is estimated that this number of survivors was probably derived from about 230,000 live births.

\section{Review of Literature}

Differences in terminology and classification make comparisons between surveys difficult, but approximately one-third of all cerebral palsy takes the form of spastic hemiplegia, one-third to one-half spastic diplegia or tetraplegia, and between one-tenth and one-quarter choreoathetosis. In premature children the commonest form is symmetrical spasticity affecting lower limbs more than upper limbs. When this is apparently limited to the lower limbs it is often called cerebral spastic paraplegia and when in addition upper limbs are affected, spastic diplegia or tetraplegia. Between 40 and $70 \%$ of children with paraplegia and between 25 and $45 \%$ of children with diplegia or tetraplegia have been reported to have a birth weight of not more than $5 \frac{1}{2} \mathrm{lb} .(2,500 \mathrm{~g}$.) (Asher and Schonell, 1950; Childs and Evans, 1954; Eastman and DeLeon, 1955; Plum, 1956; Woods, 1957; Illingworth, 1958; Hansen, 1960, and Mitchell, 1961). The same authors reported that between 24 and $37 \%$ of children with choreoathetosis and between 20 and $35 \%$ of children with spastic hemiplegia were premature.
The Syndrome of Spastic Diplegia. Paraplegia is difficult to distinguish from diplegia since upper limbs are seldom completely normal; all degrees of involvement of upper limbs are found in diplegia although they are always less affected than lower limbs. In both paraplegia and diplegia bimodal birth weight distributions have been reported with peaks around $4 \mathrm{lb}$. $(1,800 \mathrm{~g}$.) and $7 \mathrm{lb}$. $(3,200 \mathrm{~g}$.) with a rather larger proportion of paraplegics in the lower birth weight group (Childs and Evans, 1954; Fuldner, 1957). These considerations suggest that paraplegia and diplegia are different degrees of one disorder; the term diplegia is used in this paper to include paraplegia, and includes also asymmetrical cases in which lower limbs are predominantly affected.

Childs and Evans (1954) suggested that the bimodal birth weight distribution of diplegia might indicate two aetiological patterns. Supporting evidence was recently presented by Drillien, Ingram and Russell (1962) who found that the mothers of a group of diplegic children weighing over $5 \frac{1}{2} \mathrm{lb}$. $(2,500 \mathrm{~g}$.) tended to be of superior social class, older, and less fertile than the mothers of a group weighing $4 \frac{1}{2} \mathrm{lb}$. $(2,000 \mathrm{~g}$.) or less.

There is no indication that genetic factors play more than a very small part in causing diplegia, although occasionally the disease may be due to a dominant or to an autosomal recessive gene (Schwarz, 1952; Boök, 1953; Sutherland, 1957) and more rarely to a sex-linked recessive gene (Johnston and McKusick, 1962).

Birth injury, although apparently an important factor in other forms of cerebral palsy, has never been considered a probable cause of diplegia in premature infants. Freud $(1893,1897)$ suggested that some intrauterine degenerative process caused both the cerebral lesion and the premature birth. Collier $(1899,1923)$ and later Ford (1926) substantially agreed with this view. Brissaud (1894) 
thought that prematurity interfered with the development of the pyramidal tracts and postulated that the earlier delivery took place the more extensive was the motor disorder. Polani $(1958,1959)$ also considered that the damage occurred after birth and he suggested that interference, caused by prematurity, with enzymic maturation in developing structures and perhaps excess of oxygen were aetiological factors.

Spastic Hemiplegia. Spastic hemiplegia may follow an illness in early childhood, accompanied by convulsions. Perlstein and Hood (1954) and Woods (1957) thought that about one-third of the cases in their series were caused in this way; Plum (1956) and Mitchell (1961) estimated the proportion to be about one-sixth.

Birth trauma is thought to be responsible for a proportion of cases of hemiplegia and of double hemiplegia. The latter term has been used to describe children with bilateral and sometimes asymmetrical involvement in which upper limbs are more affected than lower and pseudo-bulbar palsy is often present. Autopsy examinations of infants exposed to birth trauma have shown evidence of intracranial haemorrhage and other vascular lesions (McNutt, 1885; Ford, 1926), but Norman (1933) and Stewart (1948) who had noted primitive convolutional patterns postulated an earlier origin in some cases. A higher mean birth weight in right hemiplegia compared with left, and an increased ratio of right hemiplegia to left in mature infants were found by Hood and Perlstein (1955) and by Eastman, Kohl, Maisel and Kavaler (1962). This appeared to reflect a risk of damage by the sacral promontory to the left cerebral hemisphere in larger children in the commoner left occipito-anterior presentations.

Syndromes With Choreo-athetosis. Although choreo-athetoid cerebral palsy has been less clearly defined than other types its aetiology is better understood. It can follow hyperbilirubinaemia due to rhesus and $\mathrm{ABO}$ iso-immunization or prematurity. Pathologically pigment deposition and neuronal and glial degeneration may be found in different parts of the brain, particularly the subthalamic nuclei and basal ganglia. Hyperbilirubinaemia of prematurity is probably mainly due to inability of the immature liver to conjugate lipoid-soluble bilirubin with glucuronide to form a water soluble compound that can be excreted (Claireaux, 1960).

Asphyxia at birth after a complicated delivery is frequently found in the history of children with choreo-athetosis who were not jaundiced (Evans, 1948). According to Plum (1957) this occurs both in premature and mature children.

\section{Materials and Methods}

The methods used in the survey and the frequency of the various types of clinical abnormality found have been fully described in an earlier report (McDonald, 1962). Briefly, those children weighing not more than $4 \mathrm{lb}$. $(1,800 \mathrm{~g}$.) at birth who had originally been studied in an investigation of retrolental fibroplasia by the Medical Research Council (1955) were followed up when they were from 6 to 8 years old. Of 1,128 children alive at the age of 6 months, $28(2 \cdot 5 \%)$ had by this time died, and $19(1 \cdot 7 \%)$ could not be traced, leaving 1,081 children who could be studied.

In the 1962 report 71 children were stated to have cerebral palsy. One child with mental defect and fits was originally thought to have ataxic paraplegia, but at a later examination the motor disorder was considered insufficient for a diagnosis of cerebral palsy. A diagnosis of diplegia was made in 48 of the 70 remaining, and to these were added for reasons given previously six cases of spastic lower monoplegia and three cases of spastic hemiplegia in which the lower limb was at least as much affected as the upper limb. Thus, of 70 children with cerebral palsy there were $57(81 \%)$ with the diplegic syndrome; a further five (7\%) had athetoid cerebral palsy, three $(4 \%)$ spastic double hemiplegia, two (3\%) spastic hemiplegia and three $(4 \%)$ other or mixed types.

Since the prevalence of cerebral palsy was found to vary little between centres (McDonald, 1962), the results from them all were pooled. Of the 1,081 survivors studied, 759 were single births and 322 twins or triplets; the frequency of diplegia and of other forms of cerebral palsy was 6.7 and $1.2 \%$ respectively in single infants and 1.9 and $1.2 \%$ in the multiple births.

\section{Results}

\section{1: Spastic Diplegia Syndrome}

Birth Weight and Length of Gestation. Rates of diplegia according to duration of pregnancy and birth weight are shown in Table 1 . A falling rate of diplegia was found with increasing birth weight and increasing length of gestation in both single and multiple births. In single pregnancies lasting less than 33 weeks the rate of diplegia was not related to birth weight, but in longer gestation periods the rate tended to be higher in the lower birth weight groups. There were few children in these groups and no significant association with birth weight was found other than could be accounted for by duration of pregnancy (see Appendix). The proportion of children with diplegia at each successive week of gestational age is shown in the Figure. Allowing for the small number of children with a gestation of less than 31 weeks and more than 33 weeks, a decreasing rate was evident, which contrasted with the low and steady rate of other forms of cerebral palsy.

Sex. In single children the prevalence of $8.4 \%$ 
TABLE 1

CHILDREN WITH SPASTIC DIPLEGIA AND OTHER TYPES OF CEREBRAL PALSY ACCORDING TO BIRTH WEIGHT AND LENGTH OF GESTATION

\begin{tabular}{|c|c|c|c|c|c|c|c|}
\hline \multirow{2}{*}{$\begin{array}{l}\text { Gestation } \\
\text { (wks.) }\end{array}$} & \multirow{2}{*}{$\begin{array}{l}\text { No. or Proportion } \\
\text { of Children }\end{array}$} & \multicolumn{6}{|c|}{ Birth Weight } \\
\hline & & $\begin{array}{l}-3 \mathrm{lb} .1 \mathrm{oz} . \\
(<1,388 \mathrm{~g} .)\end{array}$ & & $\begin{array}{c}3 \text { lb. } 1 \text { oz. }-<3 \text { lb. } 9 \text { oz. } \\
(1,388-<1,615 \text { g. })\end{array}$ & $\begin{array}{l}3 \text { lb. } 9 \text { oz. }-4 \text { lb. } \\
(1,615-1,814 \text { g. }\end{array}$ & & All \\
\hline-30 & $\left\{\begin{array}{l}\text { At risk } \\
\text { Diplegia }(\%) \\
\text { Other types }(\%)\end{array}\right.$ & $\begin{array}{cc}101 & 11 \cdot 9 \\
& 0\end{array}$ & & \begin{tabular}{|l|} 
Single Births \\
\\
$\quad \begin{array}{r}13.0 \\
\\
\end{array}$
\end{tabular} & $\begin{array}{r}39 \quad 12 \cdot 8 \\
2 \cdot 6\end{array}$ & 194 & $\begin{array}{r}12 \cdot 4 \\
1 \cdot 0\end{array}$ \\
\hline $31-2$ & $\left\{\begin{array}{l}\text { At risk } \\
\text { Diplegia }(\%) \\
\text { Other types }(\%)\end{array}\right.$ & $\begin{array}{ll}36 & 8 \cdot 3 \\
& 0\end{array}$ & & $\begin{array}{ll}59 & 8 \cdot 5 \\
& 0\end{array}$ & 98 & 193 & $\begin{array}{l}7 \cdot 3 \\
1 \cdot 0\end{array}$ \\
\hline $33-4$ & $\left\{\begin{array}{l}\text { At risk } \\
\text { Diplegia }(\%) \\
\text { Other types }(\%)\end{array}\right.$ & 21 & & 44 & 95 & 160 & $\begin{array}{l}3 \cdot 8 \\
1 \cdot 3\end{array}$ \\
\hline $35+$ & $\left\{\begin{array}{l}\text { At risk } \\
\text { Diplegia }(\%) \\
\text { Other types }(\%)\end{array}\right.$ & 14 & & 48 & 117 & 179 & $\begin{array}{l}2 \cdot 8 \\
1 \cdot 7\end{array}$ \\
\hline All* & $\left\{\begin{array}{l}\text { At risk } \\
\text { Diplegia }(\%) \\
\text { Other types }(\%)\end{array}\right.$ & $\begin{array}{l}9 \cdot 4 \\
0\end{array}$ & & 212 & 366 & 759 & $\begin{array}{l}6 \cdot 7 \\
1 \cdot 2\end{array}$ \\
\hline-30 & $\left\{\begin{array}{l}\text { At risk } \\
\text { Diplegia (\%) } \\
\text { Other types }(\%)\end{array}\right.$ & $\begin{array}{r}20 \\
5 \cdot 0 \\
5 \cdot 0\end{array}$ & $i i:$ & $\begin{array}{l}\text { Multiple Births } \\
13 \quad \begin{array}{r}7 \cdot 7 \\
0\end{array}\end{array}$ & 11 & 44 & $\begin{array}{l}4 \cdot 5 \\
2 \cdot 3\end{array}$ \\
\hline $31-2$ & $\left\{\begin{array}{l}\text { At risk } \\
\text { Diplegia }(\%) \\
\text { Other types }(\%)\end{array}\right.$ & $\begin{array}{ll}15 & \\
& 0 \\
& 0\end{array}$ & & 42 & 40 & 97 & $\begin{array}{l}1 \cdot 0 \\
0\end{array}$ \\
\hline $33-4$ & $\left\{\begin{array}{l}\text { At risk } \\
\text { Diplegia (\%) } \\
\text { Other types }(\%)\end{array}\right.$ & $\begin{array}{r}12 \\
16 \cdot 7 \\
8 \cdot 3\end{array}$ & & 21 & 50 & 83 & $\begin{array}{l}2 \cdot 4 \\
1 \cdot 2\end{array}$ \\
\hline $35+$ & $\left\{\begin{array}{l}\text { At risk } \\
\text { Diplegia }(\%) \\
\text { Other types }(\%)\end{array}\right.$ & 7 & & 23 & $\begin{array}{l}0 \\
4 \cdot 3\end{array}$ & 77 & $\begin{array}{l}0 \\
2 \cdot 6\end{array}$ \\
\hline All* & $\left\{\begin{array}{l}\text { At risk } \\
\text { Diplegia (\%) } \\
\text { Other types }(\%)\end{array}\right.$ & $\begin{array}{l}5 \cdot 1 \\
3 \cdot 4\end{array}$ & & 108 & $\begin{array}{l}0 \cdot 6 \\
1 \cdot 3\end{array}$ & 322 & $\begin{array}{l}1 \cdot 9 \\
1 \cdot 2\end{array}$ \\
\hline
\end{tabular}

* Including 33 single births and 21 multiple births with an unknown gestation period.

found among the 310 male children was higher than $5 \cdot 6 \%$ among the 449 female children $(\mathrm{p}=0 \cdot 17)$. Male rates were higher only at longer periods of gestation; these differences may be related to the higher average weight of male infants and the greater relative maturity of female children in the sample.

Early Postnatal History. The rate of diplegia was found to vary considerably with clinical findings in the neonatal period (Table 2). In the whole sample of single children the highest rate was found in those who had cyanotic attacks, but increased rates were found with jaundice, generalized oedema and respiratory difficulties of any kind. There was significantly more diplegia among children who were jaundiced than among those who were not (see Appendix). This was particularly true of children with a gestation period of less than 31 weeks $(p=0.03)$. Much of the excess of diplegia in

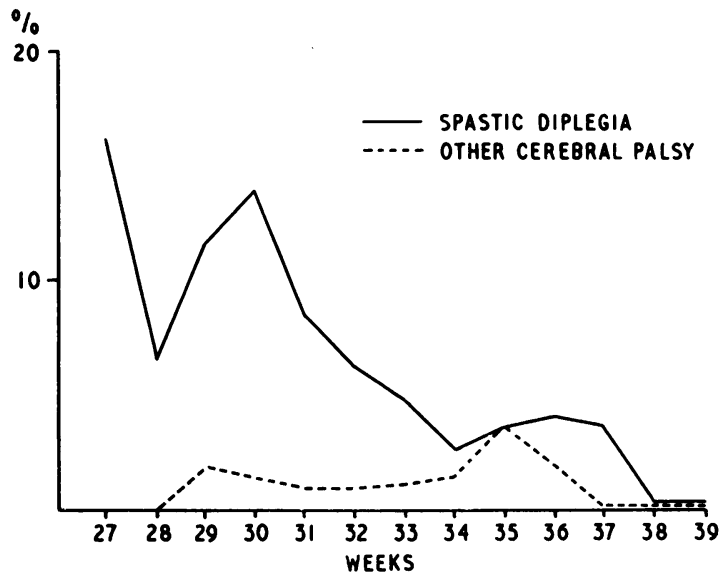

FIG.-Rate (\%) of spastic diplegia and other types of cerebral palsy in single children according to length of gestation. 
TABLE 2

SINGLE CHILDREN WITH SPASTIC DIPLEGIA AND OTHER TYPES OF CEREBRAL PALSY ACCORDING TO POSTNATAL HISTORY AND LENGTH OF GESTATION

\begin{tabular}{|c|c|c|c|c|c|c|c|c|c|}
\hline & & & \multicolumn{5}{|c|}{ Spastic Diplegia } & \multirow{3}{*}{\multicolumn{2}{|c|}{$\begin{array}{c}\text { Other } \\
\text { Types } \\
\text { of } \\
\text { Cerebral } \\
\text { Palsy }\end{array}$}} \\
\hline \multirow{2}{*}{\multicolumn{3}{|c|}{ Postnatal History }} & \multicolumn{5}{|c|}{ Gestation (wks.) } & & \\
\hline & & & -30 & $31-2$ & $33-4$ & $35+$ & All & & \\
\hline \multirow[t]{2}{*}{ aundice: } & Absent & $\begin{array}{l}\text { At risk } \\
\text { Rate \% }\end{array}$ & $\begin{array}{ll}68 & \\
& 4 \cdot 4\end{array}$ & $\begin{array}{ll}78 & \\
& 7 \cdot 7\end{array}$ & $\begin{array}{ll}83 & \\
& 3 \cdot 6\end{array}$ & $117 \quad 1 \cdot 7$ & $\begin{array}{ll}360 \quad 3.9\end{array}$ & 360 & $1 \cdot 1$ \\
\hline & Present & $\begin{array}{l}\text { At risk } \\
\text { Rate \% }\end{array}$ & ${ }^{121} 16 \cdot 5$ & $1008 \cdot 0$ & $\begin{array}{ll}70 & \\
& 4 \cdot 3\end{array}$ & $\begin{array}{ll}52 & \\
& 5 \cdot 8\end{array}$ & $\begin{array}{ll}359 & 9 \cdot 7\end{array}$ & 359 & $1 \cdot 1$ \\
\hline \multirow[t]{2}{*}{ Oedema: } & Absent & $\begin{array}{l}\text { At risk } \\
\text { Rate \% }\end{array}$ & ${ }^{88} 12 \cdot 5$ & $103 \quad 7 \cdot 8$ & $112 \quad 2 \cdot 7$ & $\begin{array}{ll}131 & \\
& 0 \cdot 8\end{array}$ & $453 \quad 5 \cdot 3$ & 453 & $1 \cdot 1$ \\
\hline & Present & $\begin{array}{l}\text { At risk } \\
\text { Rate \% }\end{array}$ & ${ }^{65} 18 \cdot 5$ & $\begin{array}{ll}64 & 7 \cdot 8\end{array}$ & ${ }^{26} 11 \cdot 5$ & ${ }^{22} 13 \cdot 6$ & ${ }^{185} 13 \cdot 0$ & 185 & $1 \cdot 6$ \\
\hline \multirow[t]{4}{*}{ Respiratory difficulties: } & Absent & $\begin{array}{l}\text { At risk } \\
\text { Rate \% }\end{array}$ & ${ }^{75} 12 \cdot 0$ & $82 \quad 7 \cdot 3$ & $1012 \cdot 0$ & $\begin{array}{ll}118 & \\
& 0.8\end{array}$ & $\begin{array}{ll}397 & 4 \cdot 5\end{array}$ & 397 & $0 \cdot 8$ \\
\hline & Present & $\begin{array}{l}\text { At risk } \\
\text { Rate \% }\end{array}$ & $10614 \cdot 2$ & $97 \quad 7 \cdot 2$ & $\begin{array}{ll}51 & 7 \cdot 8\end{array}$ & $56 \quad 7 \cdot 1$ & ${ }^{320} 10 \cdot 0$ & 320 & $1 \cdot 6$ \\
\hline & Cyanotic attacks & $\begin{array}{l}\text { At risk } \\
\text { Rate \% }\end{array}$ & $3920 \cdot 5$ & ${ }^{17} 11 \cdot 8$ & $1216 \cdot 7$ & $137 \cdot 7$ & ${ }^{83} 18 \cdot 1$ & 83 & $1 \cdot 2$ \\
\hline & Respiratory distress & $\begin{array}{l}\text { At risk } \\
\text { Rate \% }\end{array}$ & $234 \cdot 3$ & ${ }^{26} 11 \cdot 5$ & $\begin{array}{ll}9 & \\
& 0\end{array}$ & ${ }^{8} 25 \cdot 0$ & $\begin{array}{ll}68 & 8 \cdot 8\end{array}$ & 68 & $1 \cdot 5$ \\
\hline \multicolumn{2}{|c|}{ Convulsions or cerebral irritation } & $\begin{array}{l}\text { At risk } \\
\text { Rate \% }\end{array}$ & $1225 \cdot 0$ & 120 & $\begin{array}{ll}10 & \\
& 0\end{array}$ & 210 & $\begin{array}{ll}58 & 6 \cdot 9\end{array}$ & 58 & 6.9 \\
\hline \multicolumn{2}{|l|}{ All single births } & $\begin{array}{l}\text { At risk } \\
\text { Rate \% }\end{array}$ & $194 \quad 12 \cdot 4$ & $193 \quad 7 \cdot 3$ & $\begin{array}{ll}160 & \\
& 3 \cdot 8\end{array}$ & $179 \quad 2 \cdot 8$ & $759 * 6 \cdot 7$ & $759^{*}$ & $1 \cdot 2$ \\
\hline
\end{tabular}

* Including 33 children with an unknown gestation period.

children with respiratory difficulties was associated with cyanotic attacks or with respiratory distress as indicated by rib recession and grunting respiration.

The figures in Table 2 were subjected to more detailed statistical analysis by Dr. C. C. Spicer (see Appendix) to find out whether jaundice and respiratory difficulties (cyanotic attacks or respiratory distress) were independently related to diplegia after allowance had been made for length of gestation. Each was found to be independently associated with diplegia at a $5 \%$ significance level. The association with jaundice was independent of its duration.

A relation with duration of oxygen therapy was found. In children with a gestation period of less than 31 weeks there were $18(18.4 \%)$ children with diplegia out of 98 given oxygen for less than 11 days, compared with five $(5.7 \%)$ out of 87 given oxygen for 11 or more days $(p=0.02)$. In children born after longer gestation periods there was no association with oxygen therapy. The difference was, however, limited to children who had cyanotic attacks; of 14 children with a gestation period of less than 31 weeks and who had cyanotic attacks and were given oxygen for less than 11 days, eight $(57 \%)$ had diplegia compared with none of 24 com- parable children given oxygen for a longer time. Among the children with no reported cyanotic attacks, $10(12 \%)$ of 83 children given oxygen for not more than 10 days and five $(8 \%)$ of 63 children given oxygen for 11 or more days had diplegia.

After arrangement of the centres according to the median length of oxygen treatment (Table 3) the rate of diplegia in those where oxygen was given for a median period of 10 days or more was $5.8 \%$ compared with $16.0 \%$ in the remainder $(p=0.07)$. Retrolental fibroplasia showed an opposite trend from $9.6 \%$ in centres giving least oxygen to $21.7 \%$ in those with a median length of treatment of 10 days or more $(p=0.03)$. Of the 194 children of less than 31 weeks' gestation, $27(14 \%)$ had retrolental fibroplasia; only one of the 27 had diplegia whereas $3 \cdot 3$ were expected.

The rate of diplegia among single children given antibiotics was $10.3 \%$ compared with $4.1 \%$ in children not so treated $(p=0 \cdot 01)$. Allowing for the effect of gestational age, jaundice and respiratory difficulties, 25 cases of diplegia were expected in children given antibiotics, but 30 were found $(p=0.53)$ and 17 cases were expected among children not given any antibiotic compared with 
12 cases found $(\mathrm{p}=0 \cdot 21)$. There was therefore little evidence of any independent association with antibiotic therapy.

Social Class. In England and Wales in 1951, $16.5 \%$ of legitimate maternities were in classes I and II, $56 \cdot 4 \%$ in class III and $27 \cdot 1 \%$ in classes IV and V of the social class scale (Registrar-General, 1957); the comparable proportions in the present sample were $17 \cdot 0 \%, 53 \cdot 5 \%$ and $29 \cdot 5 \%$ respectively. This was at variance with the accepted association between prematurity and social class (Baird, 1962), and was perhaps partly due to the method of selection of the sample and to social class differences in survival, but social factors may be relatively unimportant in the aetiology of very low birth weight.

In three of the four gestation groups there was a slightly higher rate of diplegia in classes IV and V compared with I, II and III. Since some of this difference was possibly due to different neonatal experiences, expected numbers were calculated. In classes I and II and in illegitimate children, the numbers agreed with those observed, but in class III 24 were expected and 16 found $(p=0 \cdot 10)$ and in classes IV and V, $11 \cdot 5$ were expected and 19 found $(\mathrm{p}=0.03)$.

Maternal Age, Parity and Previous Pregnancies. These factors were studied in single pregnancies only. Of all the mothers, $41 \%$ were primigravidae and $24 \%$ had had three or more previous pregnancies, compared with $29 \%$ and $33 \%$ for mothers of children with diplegia $(\mathrm{p}=0 \cdot 18)$. The mean maternal age in diplegia did not differ from that of the whole group, and ranged from 25 years in primigravidae to 33 years in women who had had three or more previous pregnancies. There was a total of 1,204 earlier pregnancies of which $197(16.4 \%)$ were miscarriages compared with $15(19.2 \%)$ of the 78 earlier pregnancies of mothers of children with diplegia. Excluding miscarriages, in $22.5 \%$ of the 1,007 previous births the infants were premature by weight and in $7 \cdot 1 \%$ there was foetal or infant death, compared with $19.0 \%$ and $3.2 \%$ in diplegia. These differences were not statistically significant at the $5 \%$ level.

History of Pregnancy and Delivery. Because of the different rates of diplegia in multiple and single births, and the evident importance of gestational age in the aetiology of diplegia, perinatal factors were examined in single births according to length of pregnancy. The extent to which individual items of prenatal and perinatal history were recorded varied considerably, and there are possible sources of bias in those factors incompletely recorded, but
TABLE 3

RATES OF SPASTIC DIPLEGIA AND RETROLENTAL FIBROPLASIA IN CHILDREN WITH A GESTATION OF LESS THAN 31 WEEKS ACCORDING TO MEDIAN DURATION OF OXYGEN TREATMENT GIVEN AT CENTRE

\begin{tabular}{|c|c|c|c|c|}
\hline Centre & $\begin{array}{c}\text { Median } \\
\text { Duration } \\
\text { of Oxygen } \\
\text { (days) }\end{array}$ & $\begin{array}{c}\text { Total } \\
\text { Children }\end{array}$ & $\begin{array}{c}\text { Spastic } \\
\text { Diplegia } \\
(\%)\end{array}$ & $\begin{array}{c}\text { Retrolental } \\
\text { Fibroplasia } \\
\text { or Myopia } \\
\text { (-3D or more) }\end{array}$ \\
\hline $\begin{array}{r}7 \\
12 \\
11 \\
14\end{array}$ & $\begin{array}{l}0 \\
0 \\
1 \\
1\end{array}$ & 23 & $17 \cdot 4$ & $8 \cdot 7$ \\
\hline $\begin{array}{l}2 \\
8 \\
9 \\
3\end{array}$ & $\begin{array}{l}5 \\
6 \\
6 \\
8\end{array}$ & 102 & $15 \cdot 7$ & $9 \cdot 8$ \\
\hline $\begin{array}{r}1 \\
10 \\
5 \\
13 \\
6 \\
4\end{array}$ & $\begin{array}{l}10 \\
10 \\
14 \\
14 \\
15 \\
17\end{array}$ & 69 & $5 \cdot 8$ & $21 \cdot 7$ \\
\hline All & & 194 & $12 \cdot 4$ & $13 \cdot 9$ \\
\hline
\end{tabular}

recording of most of the apparently important factors was fairly complete.

Rates of diplegia at particular lengths of gestation were similar in pregnancies in which there was a history of toxaemia and of bleeding and of neither complication (Table 4). No obvious difference was found between surgically induced labours and spontaneous labours. Differences might, however, be obscured by associations between prenatal and postnatal factors; for instance, neonatal jaundice is less common in children of toxaemic than of nontoxaemic mothers (Barton, Wilson and Walker, 1962; Wood, Culley, Waterhouse and Powell, 1962). Therefore expected numbers of children with diplegia were calculated allowing for the effect of jaundice and respiratory difficulties (see Appendix). In pregnancies with toxaemia, seven children with diplegia were expected and six found; in those with bleeding 13 were expected and 10 found, and in those with a history of neither bleeding nor toxaemia 22 were expected and 26 found. The agreement between observed and expected numbers was therefore quite close. A comparison was made in a similar way between labours that were induced and those that began spontaneously. Among 121 induced labours, six cases were expected and six found, and among 546 spontaneous labours, 40 cases were expected and 40 found.

The rate of diplegia in breech deliveries of 31 or 32 weeks gestation was high $(p=0.005)$, but there was no similar trend at other gestational ages. There were few abdominal deliveries in which the period of gestation was very short, but one child with diplegia was delivered by lower segment 
TABLE 4

SINGLE CHILDREN WITH SPASTIC DIPLEGIA AND OTHER TYPES OF CEREBRAL PALSY ACCORDING TO PREGNANCY AND BIRTH HISTORY AND LENGTH OF GESTATION PERIOD

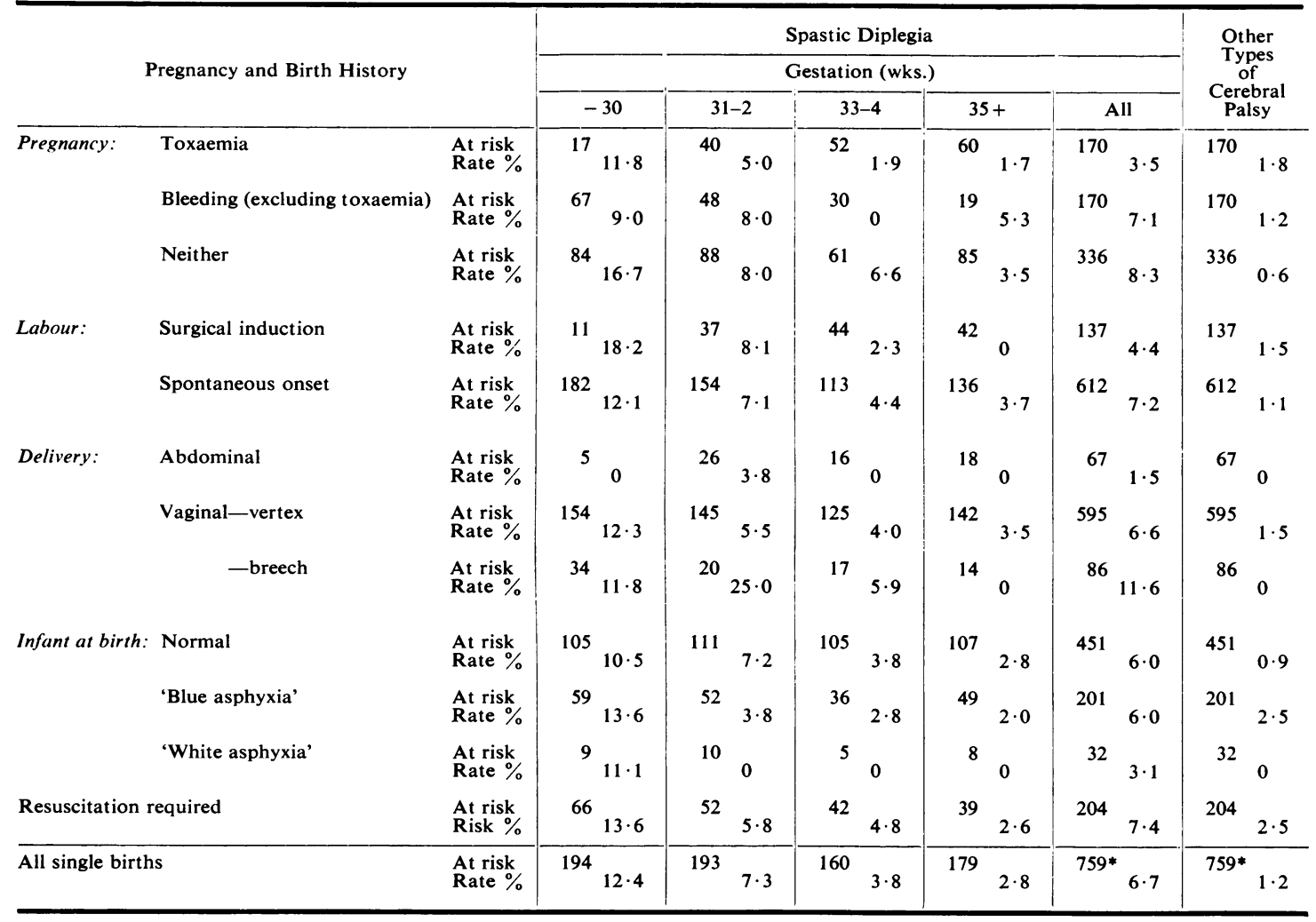

* Including 33 children with an unknown gestation period

caesarean section because of breech presentation and prolapsed cord.

There was no obvious connexion between diplegia and asphyxia noted immediately after birth, nor any excess among children receiving resuscitative treatment. In view of possible associations between asphyxia at birth and neonatal respiratory difficulties or jaundice, expected numbers of children were calculated allowing for these factors. Sixteen children with diplegia were expected to have had a history of 'blue' or 'white' asphyxia at birth, but 13 were found $(p=0 \cdot 44)$.

Multiple Births. It has already been said that there was a substantial difference in the rate of diplegia in single and multiple births, which was not explained by differences in length of gestation, and which was in contrast with findings in other types of cerebral palsy. There was no case of diplegia among the 14 triplets. In five of the six twins with diplegia the co-twin failed to survive; one of the five was a stillborn macerated foetus weighing $1 \mathrm{lb} .11 \mathrm{oz}$. (764 g.) and the other four died in the neonatal period. $10 \%$ of single children of less than 33 weeks' gestation had diplegia, compared with three $(6 \%)$ of 49 twins whose co-twin died $(p=0.37)$ and none of 68 twins whose co-twin survived and weighed $4 \mathrm{lb} .(1,814 \mathrm{~g}$.) or less $(\mathrm{p}=0 \cdot 008)$. Two cases of diplegia among 16 surviving co-twins were not included in the sample because they weighed over $4 \mathrm{lb}$. $(1,814 \mathrm{~g}$.).

Four of the six twins with diplegia were first-born and two were second-born-rates of $2.5 \%$ and $1.4 \%$ respectively. Three were in pairs of similar sex and three in pairs of unlike sex. Allowing for gestational age, jaundice was if anything commoner in twins than in single children, but cyanotic attacks differed in their frequency. Among children with a gestation period of less than 33 weeks the proportion of single children with a history of cyanotic 
TABLE 5

CLINICAL DESCRIPTION AND NEONATAL SIGNS IN 13 CHILDREN WITH CEREBRAL PALSY OTHER THAN SPASTIC DIPLEGIA

\begin{tabular}{|c|c|c|c|c|c|c|c|c|c|c|c|c|}
\hline \multirow{2}{*}{ Clinical Description } & \multirow{2}{*}{$\begin{array}{l}\text { Single } \\
\text { or } \\
\text { Twin } \\
\text { (twin } \\
\text { order) }\end{array}$} & \multicolumn{2}{|c|}{$\begin{array}{l}\text { Birth } \\
\text { Weight }\end{array}$} & \multirow{2}{*}{$\begin{array}{c}\text { Gesta- } \\
\text { tion } \\
\text { (wks.) }\end{array}$} & \multirow{2}{*}{ Present } & \multirow{2}{*}{$\begin{array}{c}\text { Jaun- } \\
\text { dice } \\
\text { Severe }\end{array}$} & \multirow{2}{*}{$\begin{array}{l}\text { Dura- } \\
\text { tion } \\
\text { (days) }\end{array}$} & \multirow{2}{*}{$\begin{array}{l}\text { Head } \\
\text { Retrac- } \\
\text { tion }\end{array}$} & \multirow{2}{*}{$\begin{array}{c}\text { Raised } \\
\text { Intra- } \\
\text { cranial } \\
\text { Pressure }\end{array}$} & \multirow{2}{*}{$\begin{array}{l}\text { Blood } \\
\text { in } \\
\text { C.S.F. }\end{array}$} & \multirow{2}{*}{$\begin{array}{c}\text { Convul- } \\
\text { sions }\end{array}$} & \multirow{2}{*}{$\begin{array}{c}\text { 'Cere- } \\
\text { bral } \\
\text { Irrita- } \\
\text { tion' }\end{array}$} \\
\hline & & lb. oz. & g. & & & & & & & & & \\
\hline Bilateral athetosis with deafness & $\mathbf{S}$ & 313 & 1,728 & 32 & + & Un- & 12 & + & & & Un- & + \\
\hline Bilateral athetosis with deafness & $\mathbf{S}$ & 36 & 1,530 & 29 & + & Yes & 28 & & & & - & + \\
\hline Bilateral athetosis (severe) & $\mathbf{S}$ & 39 & 1,615 & 35 & - & & & & & & + & \\
\hline Bilateral athetosis (mild) & $\mathbf{S}$ & 313 & 1,728 & 33 & + & Yes & 14 & & & & - & \\
\hline Bilateral athetosis (very mild) & $\mathbf{S}$ & 314 & 1,756 & 36 & - & & & & & & + & $\left(3\right.$ d day $^{+}$ \\
\hline Double hemiplegia, microcephaly & $\mathbf{T}(2)$ & 312 & 1,700 & 39 & - & & & & & + & + & ${ }_{(6 \mathrm{th}}^{+}$day) \\
\hline Double hemiplegia, microcephaly & $\mathbf{S}$ & 36 & 1,530 & 35 & - & & & & & & + & \\
\hline $\begin{array}{l}\text { Double hemiplegia, cataracts, } \\
\text { idiot }\end{array}$ & $\mathbf{S}$ & & 1,728 & 34 & - & & & & + & + & + & + \\
\hline $\begin{array}{l}\text { R. hemiplegia (onset at } 14 \mathrm{mths} \text {. } \\
\text { during blood transfusion) }\end{array}$ & $\mathbf{S}$ & 311 & 1,671 & 30 & $\begin{array}{l}\text { Un- } \\
\text { known }\end{array}$ & & & & & & $\begin{array}{l}\text { Un- } \\
\text { known }\end{array}$ & \\
\hline L. hemiplegia & $T(2)$ & 312 & 1,700 & 37 & - & & & & & (Poorly & completec & d record) \\
\hline Spastic quadriplegia with athetosis & $\mathbf{S}$ & 313 & 1,728 & 31 & + & No & 9 & & & & - & \\
\hline Spast ic quadriplegia with tremor & $\mathrm{T}(1)$ & 30 & 1,360 & 29 & + & Yes & 21 & & & & - & \\
\hline $\begin{array}{l}\text { Dystonic cerebral palsy, mental } \\
\text { defect }\end{array}$ & $\mathrm{T}(2)$ & 212 & 1,247 & 34 & + & No & 6 & + & + & & - & \\
\hline
\end{tabular}

attacks was $14.5 \%$, twins whose co-twin died, $15.9 \%$, and twins whose co-twin survived, $2 \cdot 2 \%$. The difference between single children and twins whose co-twin survived was statistically significant $(\mathrm{p}=0.003)$.

\section{2: Other Types of Cerebral Palsy}

The 13 children with other types of cerebral palsy had histories that differed in many respects from those of children with diplegia: there was no difference in rate between single and multiple births (Table 1), no trend according to gestational age (Table 1) and no indication of any association with respiratory difficulties or with jaundice or oedema (Table 2). There was, on the other hand, an excess of children with convulsions or other signs of cerebral irritation, which was not found in diplegia. Of 58 single children with such a history four $(6.9 \%)$ and two $(13.3 \%)$ of 15 twins had cerebral palsy other than diplegia. In single and multiple births combined this difference was of a significant order $(p<0.01)$. As in diplegia there was no evidence of any association with the pregnancy and birth factors examined (Table 4).

Two of the five children with athetosis had severe jaundice and probably a third (Table 5). The two children who were not jaundiced had long periods of gestation-35 and 36 weeks - and both had convulsions. The three children with double hemiplegia had long gestation periods and all three had convulsions. Typical spastic hemiplegia was found in only two cases: in one the onset was at the age of 14 months during a blood transfusion and the other case was a breech delivery in a second twin.

\section{Discussion}

The very high rate of diplegia and the relatively low rates of other types of cerebral palsy were the most striking features in this series of children of very low birth weight. Spastic hemiplegia generally accounts for about one-third of cases, but was virtually absent, whereas $80 \%$ of the children with cerebral palsy appeared to have the diplegic syndrome. The close correlation between the rate of diplegia and length of gestation suggests that immaturity was a factor of great importance in the aetiology of this, but not of other types of cerebral palsy.

Though the causes of diplegia remain uncertain, two hypotheses can probably be ruled out. The equal frequency with which diplegia followed induced and spontaneous labours and pregnancies with toxaemia or bleeding, compared with pregnancies with neither, does not support the view that 
diplegia and prematurity have a common cause. Moreover, mothers of children with diplegia did not differ from others in parity, age or past history of premature births, abortions, stillbirths or infant deaths. The second unsupported hypothesis was that asphyxia during delivery is an aetiological factor; a record of neither asphyxia nor resuscitation was unduly associated with diplegia. Admittedly, the colour of an infant immediately after delivery reflects only conditions during the previous few minutes, but those who showed asphyxia on delivery probably experienced more intrauterine asphyxia than infants with a normal colour.

Since the presence of jaundice and the period of gestation are both related, but in different ways, to the degree of immaturity, it was not surprising to find an association between spastic diplegia and jaundice, over and above that with gestational age. The possibility that hyperbilirubinaemia may itself cause spastic diplegia can probably be dismissed. There was no association with the duration of jaundice, the only available measure of severity, and in any case athetosis due to kernikterus is seldom accompanied by diplegia. Hyperbilirubinaemia in premature infants is probably due to immaturity of hepatic enzyme systems, and respiratory difficulties may contribute to it (Miller and Reed, 1958). Jaundice may therefore be taken as an indicator of enzyme immaturity which in turn may be related to the normal development of the nervous system. Generalized oedema, which was also associated with diplegia, is another indicator of immaturity. Brissaud suggested that a disturbance of myelination of the pyramidal tracts might produce paralysis of a different extent according to gestational age at birth. The findings of this survey did not support his contentions since it was the frequency and not the extent of paralysis that was related to length of pregnancy. Nevertheless, it might be by interference with myelination that an immature enzyme system might exert its effect.

Respiratory distress is also more common in immature infants, as are cyanotic attacks which are probably due to various factors, among them pulmonary insufficiency. Oxygen deficiency must occur in both cyanotic attacks and respiratory distress and their association with diplegia is consistent with the hypothesis that cerebral hypoxia during the first week or two of life is an aetiological factor. Children with reported cyanotic attacks presumably had the more severe hypoxia, and it was this group that had the highest rate of diplegia. It is therefore of considerable interest that there was evidence in very immature infants of a protective effect from prolonged oxygen therapy, and a lower rate of diplegia in centres with high rates of retrolental fibroplasia where oxygen was used for long periods. However, the lack of similar evidence in the more mature children suggests the operation of more than one factor. Oxygen therapy can certainly be discounted as a cause of diplegia and may be a useful means of preventing the disease providing that the danger of retrolental fibroplasia can be avoided.

There was no evidence that social factors contributed to the cause of prematurity in the present sample, but some indication that they may play some part in the aetiology of diplegia does exist since an increased rate of diplegia was found in social classes IV and V similar to that reported by Drillien et al. (1962).

It has often been noted that if a twin has diplegia, the co-twin may have been stillborn or have died in the neonatal period. This has been argued as an indication of a prenatal origin for diplegia, particularly as in some cases the stillborn twin was macerated. It is not incompatible with a postnatal origin, however, since intrauterine death of one twin might induce premature labour and so cause diplegia in the survivor. In this survey twins, when both survived, were less likely to develop diplegia than single infants, whereas when one died, the survivor was as likely to develop diplegia as a single infant. The difference between single and twin infants is possibly explained by a greater tendency for the single infants to have cyanotic attacks. Kinsey (1956) found that twins more readily developed retrolental fibroplasia than single infants. A greater susceptibility to damage from oxygen might be consistent with a lower risk of damage from oxygen deficiency.

Although there were only 13 children with cerebral palsy other than diplegia, this is five or six times the frequency in the general population. Of the 13, two had spastic quadriplegia and should possibly have been included with the diplegic group, and one child with dystonia and mental defect should perhaps not have been classified as cerebral palsy. The remaining 10 fall into two groups, five with athetosis and five with hemiplegia. Three of the five with athetosis had hyperbilirubinaemia of prematurity, but the long periods of gestation in the two who were not jaundiced raises the possibility of some prenatal damage associated with retarded foetal growth. In the hemiplegic group three children with double hemiplegia had a history of convulsions, which is consistent with intracranial damage during birth. Excluding the one child with unilateral hemiplegia which was almost certainly attributable to blood transfusion at 14 months, the remaining 
four children in the hemiplegic group were light in relation to their gestational age, which suggests that a prenatal factor may have been operative.

\section{Summary}

Of 1,081 children weighing not more than $4 \mathrm{lb}$. $(1,800$ g.) at birth, $70(6 \cdot 5 \%)$ developed cerebral palsy; of these $57(81 \%)$ were included in the syndrome of spastic diplegia; five $(7 \%)$ had choreo-athetoid cerebral palsy, three $(4 \%)$ had spastic double hemiplegia and only two (3\%) had typical spastic hemiplegia. These proportions are very different from those generally found among cases of cerebral palsy as a whole.

Diplegia, but nor other types, occurred more often in single than in multiple births. In single births the prevalence of diplegia increased from $2.8 \%$ following pregnancies lasting $\mathbf{3 5}$ or more weeks to $12.4 \%$ in pregnancies lasting less than 31 weeks. It appeared to occur independently of the cause of premature birth, rendering a prenatal origin unlikely. There was no indication that asphyxia in the infant during delivery was an aetiological factor.

Cyanotic attacks in the early postnatal period were found to be associated with diplegia, and it is suggested that these may either cause the disorder in immature infants or be closely associated with the cause. Association with jaundice and to a lesser extent with oedema was found, which it is suggested might be explained on the grounds that jaundice and oedema are indicative of immaturity. The relatively low rate of diplegia found in twins whose co-twin survived was perhaps explained by a lower rate of cyanotic attacks.

There was some indication that prolonged oxygen therapy prevented diplegia in very immature infants with cyanotic attacks. It is suggested that this treatment may be of value if retrolental fibroplasia can be avoided.

Other types of cerebral palsy differed in that they showed a significant association with convulsions or signs of cerebral irritation in the neonatal period, but not with factors associated with diplegia. In three of five children with athetosis, hyperbilirubinaemia was the probable cause, and in the other two and in four hemiplegic children prenatal damage seemed likely.

I am very grateful to the Medical Research Council for permission to use their detailed birth records, to Principal School Medical Officers and their staffs for carrying out the survey of the children, and to Dr. C. C. Spicer for statistical help.

The work was supported by the National Spastics Society.
REFERENCES

Asher, P. and Schonell, F. E. (1950). A survey of 400 cases of cerebral palsy in childhood. Arch. Dis. Childh., 25, 360.

Baird, D. (1962). Environmental and obstetrical factors in prematurity, with special reference to experience in Aberdeen Bull. Wld Hlth Org., 26, 291.

Barton, M. E., Wilson, J. and Walker, W. (1962). Idiopathic jaundice in premature infants. Lancet, $2,847$.

Boök, J. A. (1953). A genetic and neuropsychiatric investigation of a North-Swedish population. Part II. Mental deficiency and convulsive disorders. Acta genet., 4, 345.

Brissaud, E. (1894). Maladie de Little et tabes spasmodique. Sem. méd. (Paris), 14, 89.

Childs, B. and Evans, P. R. (1954). Birth weights of children with cerebral palsy. Lancet, 1,642 .

Claireaux, A. D. (1960). Neonatal hyperbilirubinaemia. Brit. med.J., $1,1528$.

Collier, J. S. (1899). Cerebral diplegia. Brain, 22, 373.

(1923). The pathogenesis of cerebral diplegia. Lancet, 2, 1129. rillien, C. M., Ingram, T. T. S. and Russell, E. M. (1962). Comparative aetiological studies of congenital diplegia in Scotland. parch. Dis. Childh., 37, 282.
Arch.

Eastman, N. J. and DeLeon, M. (1955). The etiology of cerebral palsy. Amer. J. Obstet. Gynec., 69, 950.

, Kohl, S. G., Maisel, J. E. and Kavaler, F. (1962). The obstetrical background of 753 cases of cerebral palsy. Obstet. gynec. Surv., 17, 459.

Evans, P. R. (1948). Antecedents of infantile cerebral palsy. Arch.

Ford, F. Childh. (1926). 213 . Cerebral birth injuries and their results. Medicine (Baltimore), 5,121 .

Freud, S. (1893). Zur kenntniss des cerebralen Diplegien des Kindesalters. In Anschluss an die Little'sche Krankheit. Deuticke, Vienna.

(1897). Die infantile Cerebrallahmung. In Spezielle pathologie und therapie, ed. H. Nothnagel, Band IX, Thiel II, Abt. II. Hölder, Vienna.

Fuldner, R. V. (1957). Labor complications and cerebral palsy. Amer. J. Obstet. Gynec., 74, 159.

Gibson, J. R. and McKeown, T. (1951). Observations on all births $(23,970)$ in Birmingham, 1947. III. Survival. Brit. J. soc. Med. $5,177$.

Hansen, E. (1960). Cerebral Palsy in Denmark. Munksgaard, Copenhagen.

Hood, P. N. and Perlstein, M. A. (1955). Infantile spastic hemiplegia. IV. Birth weights. Pediatrics, 16, 470.

Illingworth, R. S. (1958). Recent Advances in Cerebral Palsy. Churchill, London.

Johnston, A. W. and McKusick, V. A. (1962). A sex-linked recessive form of spastic paraplegia. Amer. J. hum. Genet., 14, 83.

Kinsey, V. E. (1956). Retrolental fibroplasia-co-operative study of retrolental fibroplasia and the use of oxygen. Arch. Ophthal., 56,481 .

McDonald, A. D. (1962). Neurological and ophthalmic disorders in children of very low birth weight. Brit. med. J., 1, 895 .

McNutt, S. J. (1885). Apoplexia neonatorum. Amer. J. Obstet. Dis. Wom., 18, 73 .

Medical Research Council (1955). Report to the Medical Research Council by their Conference on retrolental fibroplasia in the United Kingdom. Brit. med. J., 2, 78

Miller, C. A. and Reed, H. R. (1958). The relation of serum concentrations of bilirubin to respiratory function of premature infants. Pediatrics, 21, 362.

Mitchell, R. G. (1961). In Cerebral Palsy in Childhood and Adolescence-a Medical, Psychological and Social Study, ed. J. L. Henderson. Livingstone, Edinburgh.

Norman, R. M. (1933). Neurological abnormalities associated with the undeveloped cerebral cortex of the mental defective. In Stoke Park Monographs on Mental Deficiency, No. 1: The Burden Memorial Volume, p. 151. Macmillan, London.

Perlstein, M. A. and Hood, P. N. (1954). Infantile spastic hemiplegia. I. Incidence. Pediatrics, 14, 436.

Plum, P. (1956). Cerebral palsy-A clinical survey of 543 cases. Dan. med. Bull., 3, 99.

(1957). Etiology of congenital athetosis. Ann. Paediat. Fenn., $3,589$.

Polani, P. E. (1958). Prematurity and 'cerebral palsy'. Brit. med.J., 2, 1497.

(1959). Effects of abnormal brain development on function. Cerebr. Palsy Bull., 1, No. 7, p. 27.

Registrar-General (1957). Decennial Supplement, 1951. Occupational mortality, Part II, Vol. 2. H.M.S.O., London.

Schwarz, G. A. (1952). Hereditary (familial) spastic paraplegia. Arch Neurol. Psychiat. (Chic.), 68, 655.

Stewart, R. M. (1948). Infantile cerebral hemiplegia-clinical features and pathological anatomy. Edinb. med. J., 55, 488.

Sutherland, J. M. (1957). Familial spastic paraplegia;'its relation to mental and cardiac abnormalities. Lancet, 2, 169. 
Wood, B. S. B., Culley, P. E., Waterhouse, J. A. H. and Powell, D. J. (1962). Factors influencing neonatal jaundice. Arch. Dis. Childh., 37, 371

Woods, G. E. (1957). Cerebral Palsy in Childhood. Wright, Bristol.

\section{Appendix}

Statistical note by $C$. C. Spicer

The analysis of complex tables of proportions in which each proportion is classified according to several interrelated factors can be done using a method proposed by Cochran (1940) and since developed by others (e.g. Yates, 1955; Jolly, 1950; Dyke and Patterson, 1952). The calculations are laborious but well suited to electronic computation and the present study was analysed using a programme written by the author of this note for the Ferranti Mercury.

The general technique used is to transform the proportions to a logit scale and then fit constants by least squares for each factor in the usual way, using weights and working logits. The effects of the factors can then be tested by comparing them to their standard errors. The use of a logit transformation can be expected to make the effects of the factors more nearly additive, largely by extending the range of variation of the proportions which are otherwise forced to lie between 0 and $100 \%$. The adequacy of the mathematical model can be tested by calculating $\chi^{2}$ for the differences between observed and expected numbers.

In the present analysis it would have been possible, in principle, to have tested all factors simultaneously by applying the model to a complex multi-way table of the whole data. However, this would have meant that many of the proportions were based on very small numbers and might have concealed anomalies and interactions among the factors. For this reason a piecemeal approach was adopted in which the effects of the factors considered most likely to be important were calculated first. Comparisons between other factors were then made by calculating expected numbers using the constants fitted previously.

The factors for which constants were fitted were: gestation period; birth weight; presence or absence of jaundice; presence or absence of cyanotic attacks or respiratory distress.

It was found that there was no relation between diplegia and birth weight when gestation period was taken into account, and this was dropped from the analysis. It was also apparent that there was a good linear relation between logits and length of gestation.

The constants for the factors fitted in this way, together with their standard errors were: gestation (linear term), $-0.0938 \pm 0.0394 ;$ jaundice, $0.373 \pm 0.171$; cyanotic attacks or respiratory distress, $0 \cdot 448 \pm 0 \cdot 163 ; \chi^{2}, 17 \cdot 47$ (12 D.F.).

It seems from this analysis that length of gestation, jaundice and cyanotic attacks or respiratory distress are all associated with diplegia, since all the relevant constants exceed twice their standard errors.

In ordinary terms these constants imply that an increase of two weeks in gestation period reduces the odds in favour of a baby being diplegic by about $10 \%$. The presence of jaundice increases the odds in favour of diplegia by about $45 \%$, and cyanotic attacks or respiratory distress increases the odds for diplegia by about $55 \%$.

The method outlined above was used because it seemed to be the only approach at present available to the problem of testing statistical significance in complex tables of proportions. It must be admitted that experience with this type of analysis is still somewhat limited and it does not rest on as strong a basis as the ordinary analysis of variance. However, the results obtained seem intrinsically reasonable and it appears likely that the model is sufficiently realistic.

\section{REFERENCES}

Cochran, W. G. (1940). The analysis of variance when experimental errors follow the Poisson or binomial laws. Ann. math. Statist., $11,335$.

Dyke, G. V. and Patterson, H. D. (1952). Analysis of factorial arrangements when the data are proportions. Biometrics, 8, 1 . Jolly, G. M. (1950). The use of probits in combining percentage kills. Ann. appl. Biol., 37, 597.

Yates, F. (1955). The use of transformations and maximum likelihood in the analysis of quantal experiments involving two treatments. Biometrika, 42, 382. 